\title{
A family study of coarctation of the aorta
}

\author{
A. R. BOON and D. F. ROBERTS \\ From the Department of Human Genetics, University of Newcastle
}

Summary. Families of 100 patients with coarctation of the aorta and 50 controls for age, sex, and social status were studied to assess the influence of genetic and environmental variables in the aetiology.

A tendency to familial aggregation of the condition and other congenital heart defects compatible with multifactorial inheritance was discerned. Recurrence risk for sibs is approximately 1 in 200 for coarctation of the aorta, and $1 \%$ for any form of congenital heart defect. The heritability of coarctation is estimated at $58 \%$. The tendency for other non-cardiac defects to occur in the patients with coarctation does not appear in their sibs and is not so pronounced as in some other congenital heart conditions.

Of the several environmental variables examined, there was no definitive association with any other than season of birth, which implies a possible association with maternal infection; there is also a suggestion of a paternal age effect, but these require investigation in a prospective survey.

There have been few population studies of coarctation of the aorta, and, though several authors have reported more than one member of a family to be affected by the same defect (McNamara and Rosenberg, 1968), familial recurrence is thought to be rare. This survey in the north-east of England was conducted to examine the extent of any hereditary component that there may be in the aetiology of coarctation, and to compare the results with those from a similar previous study of patients with the tetralogy of Fallot (Boon et al, 1972).

Historically, the condition was first described by Morgagni in 1760 when he performed a necropsy on a monk and reported that 'the aorta was contracted to an amazing narrowness near the heart'. In 1835 Le Grand made the first clinical diagnosis of obstruction in the aorta which was later confirmed by necropsy. Thirteen years later (1848) Oppolzer precisely localized, before death, the obstruction to the isthmus of the thoracic aorta. Advances in radiology in 1928 and 1929 showed evidence of rib notching caused by bone erosion resulting from the dilated intercostal arteries which form part of the collateral circulation. The criteria, suggested by Wernicke in 1875, for the diagnosis of coarctation

Received 17 November 1975. are still accepted today; namely, the formation of a collateral circulation; pulsation in the interscapular area; dilated intercostal arteries; murmurs over the anastomotic vessels; and a discrepancy between the size of the pulse in arms and legs.

Several classifications of the condition have been proposed. In 1903 Bonnet divided coarctation of the aorta into 'infantile' and 'adult' types, a fundamental distinction that remains today though this terminology is confusing since infants may suffer from the 'adult' type of defect. The expanded classification of Johnson et al (1951) introduced three variables, a persistent ductus arteriosus, the relation of the aortic end of the ductus to the coarctation, and the presence of an adequate collateral circulation, and stressed the importance of haemodynamic as well as anatomical considerations. In Watson's (1970) most recent classification the coarctation may be situated in the preductal, juxtaductal, or postductal position. The infantile type of coarctation corresponding to the first of these is usually a diffuse narrowing, proximal to the ductus which is frequently patent, and is often associated with other heart defects. The 'adult' type corresponds to the third of these, and usually occurs as an isolated malformation, a localized constriction just distal to the entrance of the ductus arteriosus 
which forms part of the ligamentum arteriosum on closure.

The arch of the aorta develops from the fourth and the ductus arteriosus from the sixth embryonic arches. The segment of the aorta lying distal to the left subclavian artery and proximal to the entrance of the ductus has a very small blood flow during fetal life. Blood from the left ventricle is directed into the head and upper extremities via the main vessels above this segment and the circulation to the lower part of the body passes from the right ventricle via the ductus arteriosus and the descending aorta. The portion of the aorta between the left subclavian artery and ductus known as the 'isthmus' begins to function as the ductus closes, and gradually opens up to connect the cephalic and caudal circulations.

Coarctation of the aorta occurs in the region of the junction of the fourth and sixth arches. For its development three theories were initially put forward (Abbott, 1928; Blackford, 1928; Bonnet, 1903):

(i) There is persistent narrowing of the isthmus, under the influence of traction of the obliterating ductus (pseudocoarctation).

(ii) Abnormality of the isthmus occurs during the joining up of the embryonic arches.

(iii) Closure of the ductus and proliferation of the intima into the aorta produces fibrosis and constriction.

It seems likely that the different anatomical forms are brought about in different ways. According to the skodaic theory (Taussig, 1960) the adult type of coarctation is the result of an extension of the intimal tissue of the ductus arteriosus penetrating into the adjacent part of the aorta. As obliteration of the duct occurs, this tissue contracts causing the aortic constriction. This condition would, therefore, not be present at birth.

\section{Subjects and methods}

This survey covers the families of 100 index patients with coarctation of the aorta, currently attending the Newcastle Royal Victoria Infirmary and the Newcastle General Hospital. Diagnosis was confirmed by catheterization or operation in 94 cases. Fifty control families were obtained with the help of the family doctor who was asked to match the propositus with a normal child of the same age, sex, social status, and area of residence.

There were 65 male and 35 female propositi, giving a sex ratio of 1.85 . Buccal smears were done on all the female propositae to ensure that cases of Turner's syndrome were omitted from the series. Two of the index patients were members of pairs of dizygotic twins, the co-twin being unaffected in each case. There was one family where the paternal grandparents were first cousins.

From interviews with all families, information was obtained regarding their members, physical examination of the nearest relatives was carried out whenever possible, and histories of relatives of remoter degree examined. Any relative suspected of having a congenital heart condition was followed up through hospital records, death certificate, or the family doctor in order to ascertain the type of heart defect if any. The mothers were asked about their health, infections contracted, and drugs taken during the first trimester.

\section{Type of defect}

Clinically, the propositi were divided into 3 groups.

(1) The preductal group contained 8 boys and 5 girls, most of whom were diagnosed in the neonatal period and all within the first few weeks of life. They all had associated cardiac defects and 9 died before the age of 2 months (Fig. 1A).
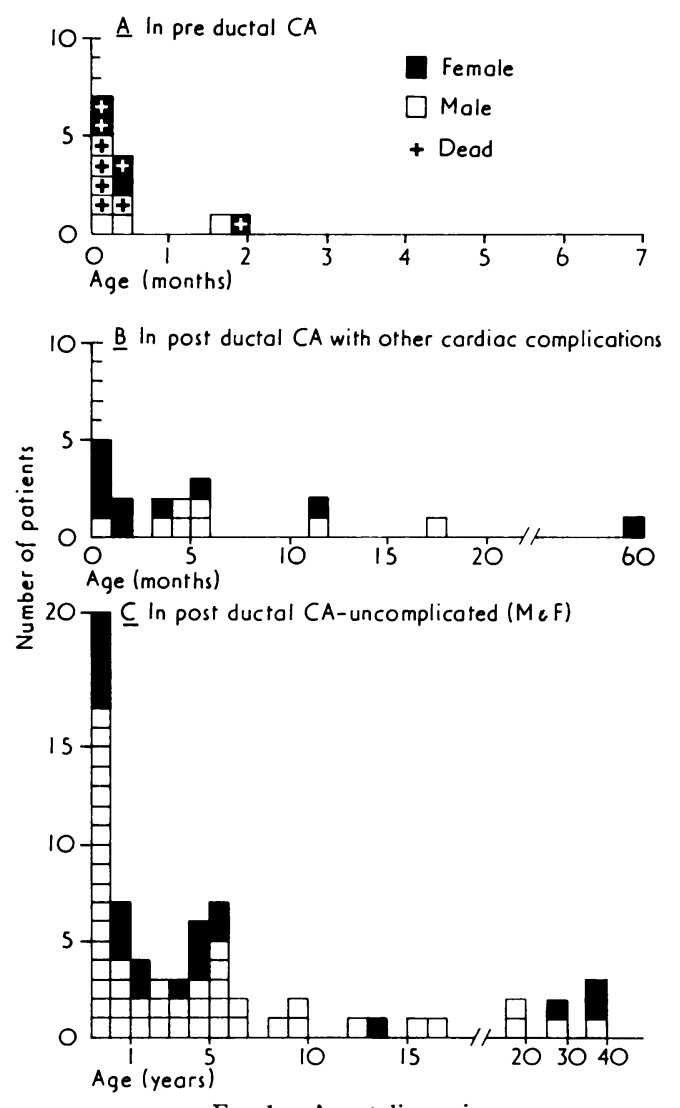

FIg. 1. Age at diagnosis. 
(2) The postductal group with complications consisted of 9 boys and 10 girls, in whom the age of diagnosis was spread out over months (Fig. 1B). All the girls had a persistent ductus arteriosus, 3 had a residual ventricular septal defect, and 2 had aortic stenosis. Of the 9 boys, only 5 had a persistent ductus arteriosus, and 2 of these had an additional ventricular septal defect; 2 had a ventricular septal defect only, one had endocardial fibroelastosis, and one an atrial septal defect with mitral incompetence. Abnormality of the aortic valve is frequently associated with coarctation of the aorta and at least $50 \%$ of the entire series were known to have bicuspid valves.

(3) The postductal group without other cardiac lesions contained 48 boys and 20 girls. Though in this group the age of diagnosis was spread over years rather than months, 29 were found in the first year of life (Fig. 1C). These infants presented with feeding difficulties, failure to thrive, or respiratory infections.

\section{Diagnosis}

Age at diagnosis varied with the type of condition but in the majority of cases was made in the first year. With rare exceptions, diagnosis after 1 year was confined to the postductal, uncomplicated coarctations. From 1 to 5 years infections are common, and the heart murmur may be heard incidentally at the time of the illness; of the 16 diagnosed at this age, 5 were found by chance during an attack of measles. Routine examination at school entry showed 10 children with heart murmurs which had not previously been suspected. Five boys were admitted to hospital for treatment of an unrelated surgical condition and a heart murmur was noticed then for the first time.

Two children collapsed in the street without apparent reason and on subsequent examination the diagnosis of a heart defect was made. A third boy developed a left-sided hemiplegia at the age of 5 years. During investigation in hospital, a youth of 17 years admitted with haematuria was found to have a coarctation, and in one woman diagnosis was made during investigation of hypertension in the early stages of her first pregnancy at the age of 27 years. The presence of a coarctation had been masked in another woman by two attacks of rheumatic fever during adolescence and she spent one year in a wheel chair. After marriage she had been advised to refrain from having a family but she proceeded to have four successful pregnancies; the fifth pregnancy was terminated because of her heart condition and she was then sterilized. The diagnosis of coarctation was first made at the age of $\mathbf{4 2}$ years, but she postponed operative treatment until she was 50 when her family no longer depended upon her.

Two men had been rejected for army service at the ages of 18 and 23 years but a diagnosis was not made at that time. They were subsequently admitted to hospital for diagnosis and treatment at the ages of 34 and 28 years, respectively. The oldest patient in the series was a man of 57 who was first diagnosed at 46 years of age when he complained of 'blackouts'. It was felt at that time that an operation posed a risk too high to take. However, with the greater experience and surgical skill achieved during the past 10 years he was advised to have the coarctation resected at the age of 53 . He made a good recovery and his hypertension greatly improved.

\section{Birthweights}

The preductal group did not differ in birthweight from the two postductal groups and were, therefore, included in the series with them. The propositi were not noted to be of low birthweight, but the figures show that the affected males tended to this; their mean weight was $3212 \pm 77 \mathrm{~g}$ by comparison with their normal brothers (mean $3379 \pm 49 \mathrm{~g}$ ) and with the control male group (mean $3452 \pm 77 \mathrm{~g}$ ). This trend did not occur in the fewer affected females who had a mean of $3289 \pm 113 \mathrm{~g}$, the control females a mean of $3117 \pm 108 \mathrm{~g}$, and their normal sisters a mean of $3266 \pm 59 \mathrm{~g}$. These figures exclude 3 premature births and 5 adults whose birthweights were not known. These differences are not statistically significant.

\section{Results}

\section{Environmental factors}

Family environment. The ages of 100 mothers and 93 fathers at the birth of the affected child were known.

The mean difference between them was $3.25 \pm$ 0.51 as compared with $3.02 \pm 0.56$ years in the controls, and 2.3 years in the general population (Penrose, 1955). The difference from the controls is not significant, and the difference from Penrose's figure for the general population may well be the result of a different pattern of marriage in the northeast population.

Table I shows the maternal age at birth of propositus and, for comparison, the number expected in each maternal age group according to the Registrar General's figures (1960), and those in the control series. The difference from the Registrar General's figures is not significant, but it is of interest that there is a slight excess of mothers over 30. There is a similar tendency by comparison 
with the controls. The mean maternal age at the birth of the propositus was $28.26 \pm 0.63$, while the mother's age at the birth of the control children was $27.86 \pm 0.81$. Similarly, there is a slight difference in the distribution of paternal ages at the birth of the propositus (Table I) significant at 5\%. Again there is a slight excess of fathers over 30 by comparison with the numbers expected from the Registrar General's figures, and by comparison with the control series. The mean paternal age at the birth of the propositi was $31.0 \pm 0.86$ with a standard devi- ation of 7.90. The parents of the 9 children who died with preductal coarctation were younger than the majority (mothers 25.35, fathers 26.75 ) but 7 of these children were the first-born of the family.

The distribution of the mothers of propositi by parity and age is shown in Table II, together with the parity distribution expected from the Registrar General's figures for the northern region. Fortyone propositi were the first-born in the family, which compared very closely with the expected figure, and 13 propositi were the last in families of 4 or more

TABLE I

PARENTAL AGE AT BIRTH OF PROPOSITUS

\begin{tabular}{|c|c|c|c|c|c|c|c|c|}
\hline & & $<20$ & $20-24$ & $\underset{25-29}{\operatorname{Par}}$ & $\begin{array}{r}\text { rental Age } \\
30-34\end{array}$ & \multicolumn{2}{|l|}{$35-39$} & $40+$ \\
\hline $\begin{array}{l}\text { Propositi } \\
\text { Controls }\end{array}$ & $\begin{array}{l}\text { No. observed }(100) \\
\text { No. expected }(100) \\
\text { No. observed }(50)\end{array}$ & $\begin{array}{l}5 \\
5.9\end{array}$ & $\begin{array}{l}29 \\
29.2 \\
16\end{array}$ & $\begin{array}{l}29 \\
28.9 \\
16\end{array}$ & $\begin{array}{c}\text { Maternal } \\
20 \\
18.3 \\
9\end{array}$ & $\begin{array}{l}12 \\
12.5 \\
5\end{array}$ & & $\begin{array}{l}5 \\
2\end{array}$ \\
\hline Propositi & No. observed (93) & - & 19 & 18 & $\underset{34}{\text { Paternal }}$ & 12 & & 10 \\
\hline \multirow[t]{2}{*}{ Controls } & \multirow[t]{2}{*}{$\begin{array}{ll}\text { No. expected } & (93) \\
\text { No. observed } & (50)\end{array}$} & \multirow[t]{2}{*}{ 二 } & \multirow[t]{2}{*}{$\frac{21.3}{6}$} & \multirow[t]{2}{*}{$\begin{array}{l}29.1 \\
19\end{array}$} & \multirow[t]{2}{*}{$\begin{array}{l}22.8 \\
15\end{array}$} & 3 & $\begin{array}{l}22 \\
20.6\end{array}$ & 7 \\
\hline & & & & & & & 10 & \\
\hline
\end{tabular}

TABLE II

MATERNAL DISTRIBUTION BY PARITY AND AGE

\begin{tabular}{|c|c|c|c|c|c|c|c|c|c|c|}
\hline \multirow{2}{*}{\multicolumn{2}{|c|}{$\begin{array}{l}\text { Age of Mother at Birth of Propositus } \\
(y)\end{array}$}} & \multicolumn{8}{|c|}{ Number of Previous Liveborn Children } & \multirow{2}{*}{ Total } \\
\hline & & 0 & 1 & 2 & 3 & 4 & 5 & 6 & $7+$ & \\
\hline \multicolumn{2}{|l|}{$\begin{array}{l}15-19 \\
20-24 \\
25-29 \\
30-34 \\
35-39 \\
40-44\end{array}$} & $\begin{array}{r}5 \\
15 \\
11 \\
6 \\
2 \\
2\end{array}$ & $\begin{array}{l}0 \\
8 \\
9 \\
6 \\
3 \\
0\end{array}$ & $\begin{array}{l}0 \\
5 \\
4 \\
5 \\
2 \\
0\end{array}$ & $\begin{array}{l}0 \\
1 \\
2 \\
0 \\
1 \\
0\end{array}$ & $\begin{array}{l}0 \\
0 \\
2 \\
2 \\
2 \\
0\end{array}$ & $\begin{array}{l}0 \\
0 \\
1 \\
1 \\
1 \\
0\end{array}$ & $\begin{array}{l}0 \\
0 \\
0 \\
0 \\
0 \\
1\end{array}$ & $\begin{array}{l}0 \\
0 \\
0 \\
0 \\
1 \\
2\end{array}$ & $\begin{array}{r}5 \\
29 \\
29 \\
20 \\
12 \\
5\end{array}$ \\
\hline Mothers of propositi & $\begin{array}{l}\text { No. observed } \\
\text { No. expected }\end{array}$ & $\begin{array}{l}41 \\
37.3\end{array}$ & $\begin{array}{l}26 \\
30.6\end{array}$ & $\begin{array}{l}16 \\
16.2\end{array}$ & $\begin{array}{l}4 \\
7.7\end{array}$ & $\begin{array}{l}6 \\
3.8\end{array}$ & $\begin{array}{l}3 \\
2.0\end{array}$ & 1.1 & $\begin{array}{l}3 \\
1.3\end{array}$ & \\
\hline
\end{tabular}

TABLE III

RESULTS OF PREGNANCIES IN MOTHERS OF PROPOSITI

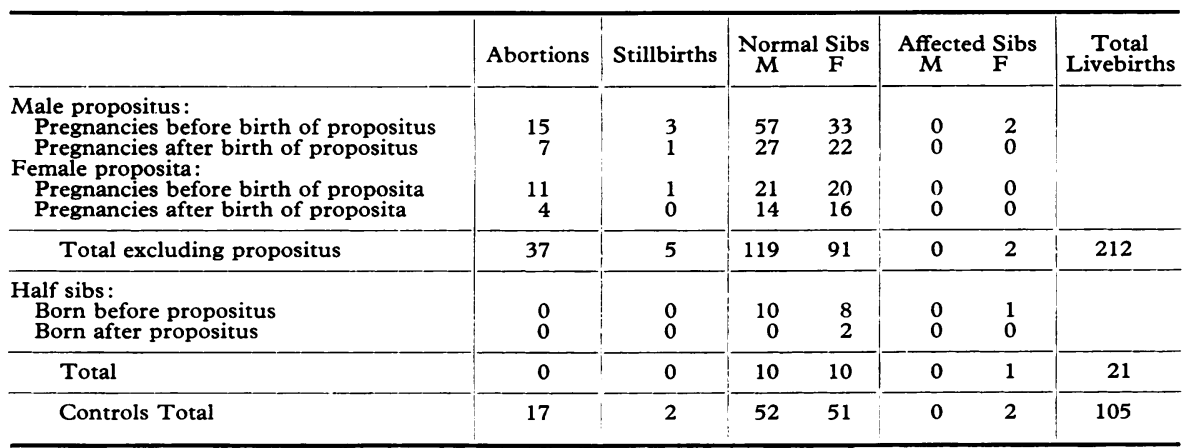


children, rather more than expected. Overall, however, the observed distribution does not depart significantly from that expected.

As regards reproductive history, the mothers had a total of 275 pregnancies excluding the propositi, of which 233 resulted in live births. Twenty-one of these were by a different father, producing halfsibs of the propositi, so that there were 212 successful full-sib pregnancies (Table III). In addition there were 37 early abortions, and 5 stillbirths, of which 2 produced hydrocephalic infants, 1 anencephalic, 1 a macerated fetus (cause unknown), and the fifth fetus died as a result of severe toxaemia in the mother. Overall, the figures compare favourably with the control group, where there were 17 abortions, and 2 stillbirths from a total of 124 pregnancies. There is general similarity in the outcome of the pregnancies before and after the affected child. More pregnancies took place before that producing the propositus than afterwards. The possible explanation, that affected children tend to occur in later pregnancies, is excluded by the data in Table II, leaving as the more likely explanation that the birth of an affected child limits the subsequent family building.

\section{TABLE IV}

DISTRIBUTION OF FAMILIES OF PROPOSITI ACCORDING TO SOCIOECONOMIC CLASS OF FATHER

\begin{tabular}{l|cccc|c}
\hline & \multicolumn{4}{|c|}{ Social class } & \multicolumn{1}{c|}{$\begin{array}{c}\text { Mothers } \\
\text { only }\end{array}$} \\
\hline $\begin{array}{l}\text { No. observed } \\
\text { No. expected }\end{array}$ & $1+2$ & 3 & 4 & 5 & 6 \\
\hline
\end{tabular}

Table IV shows the distribution of the families of the propositi according to social class as indicated by occupation of the father. This was compared with the Registrar General's (1960) figures and again there was no significant differences, though there is a tendency for a slight excess to occur in classes 4 and 5 ; this would be compatible with an effect of some extraneous environmental factor that distinguishes these two social classes from the others, and indicates the need for further data on this point.

Seasonal variation. Our numbers are small (Table V, Fig. 2) but there is a significant departure

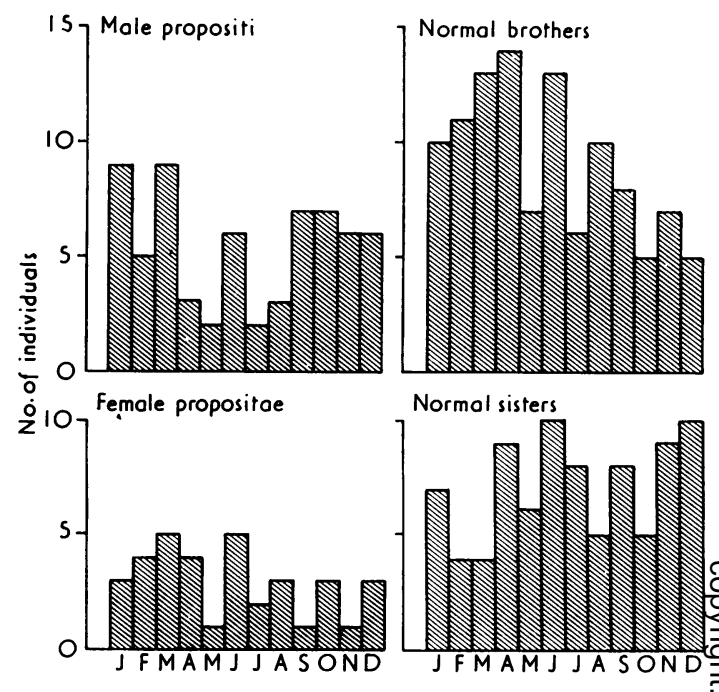

Fig. 2. Month of birth.

of birth month of propositi from the distribution in normal sibs, with a deficiency of births between April and August, a pronounced excess in January to March and a less pronounced excess from October to December. This suggests that the mothers were in contact with some environmental hazard

TABLE V

MONTH OF BIRTH OF INDEX PATIENTS AND THEIR NORMAL SIBS

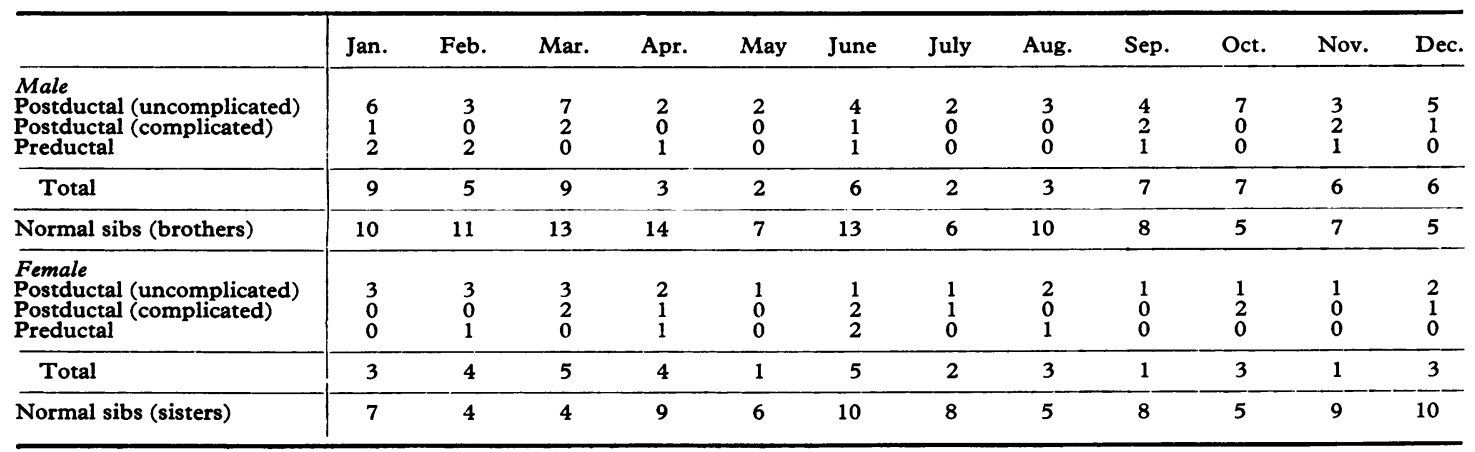


during the months of conception and initial development early in the year. The numbers are too small for separate analysis by type of coarctation, or by sex, but for the numerically more satisfactory male series the difference in distribution from their normal brothers is indeed highly significant at $1 \%$.

Maternal health. The state of health of the mothers immediately before the relevant pregnancy and during the first trimester was generally similar in the affected and control group. Two mothers of propositi had been in contact with rubella, for which they were given prophylactic gamma globulin. One of these mothers also took prednisone for asthma during the first trimester. Four mothers had hyperemesis, of whom 2 were treated with antiemetic drugs. Only 2 had experienced vaginal bleeding early in pregnancy which had lasted 1 and 3 days, respectively. One mother was vaccinated at 8 weeks' gestation and had a severe reaction for a week afterwards. Twelve mothers smoked 10 or more cigarettes daily. A variety of drugs including aspirin (1), codeine (2), quinidine (1), sodium amytal (1), morphia (1), streptomycin (1), orphenadrine (1), antihistamine (1), and trihextane slimming pills (1) were taken by a further 10 mothers in the series.

These findings compared favourably with the histories in the 50 control mothers where it was found that 10 of these had experienced hyperemesis, 4 of whom took antiemetic drugs; 10 mothers smoked 10 or more cigarettes daily, and 2 experienced vaginal bleeding during the first trimester. Two mothers had gastrointestinal infections at 7 and 12 weeks' gestation, one received rubella gamma globulin, and one had an $x$-ray film of the lumbar region and IVP at 6 weeks' pregnancy. However, compared with the propositi's mothers, there appeared to be slightly fewer taking drugs during the first trimester: one mother took quinidine for palpitations and another was given hormone treatment after two miscarriages, when she became pregnant with the control child, and one took BiSoDol for a mild stomach upset.

Family history. The tendency for congenital cardiac lesions to occur in other members of the family is well known. However, the tendency in this survey of coarctation of the aorta was not as pronounced as in studies of other types of heart defect, e.g. atrial ventricular defects, atrial septal defects, Fallot's tetralogy. Difficulties were encountered in establishing the type of congenital heart disease reported in several relatives because of insufficient information on the death certificate. The results are set out in Table VI and Appendices I and II.
TABLE VI

NUMBER OF FAMILIES WITH AT LEAST ONE AFFECTED RELATIVE

\begin{tabular}{l|c|c}
\hline & CA Group & Control Group \\
\hline $\begin{array}{l}\text { Relatives with congenital heart } \\
\text { disease }\end{array}$ & $18^{*}(22)$ & 4 \\
$\begin{array}{l}\text { Relatives with coarctation of the } \\
\text { aorta }\end{array}$ & 3 & 0 \\
\begin{tabular}{l} 
Total no. of families \\
\hline
\end{tabular} & 100 & 50 \\
\hline
\end{tabular}

* 3 families had 2 or 3 affected relatives.

Seven of the index patients had produced 4 sons and 4 daughters, all of whom were normal. Of the 195 known parents of the propositi, 2 mothers were born with a ventricular septal defect. Among sibs, 1 dead sister has been included as affected because the mother had been told by the family doctor that the child had congenital heart disease and would only survive a short time. Four sibs were found to have heart murmurs which were thought to be clinically insignificant, but cardiac catheterization was not justified and they were not therefore included as affected. One sister (Fig. 3), when medically examined at age 18 , was found to have a heart murmur, then attributed to a mild pulmonary stenosis. The control series of 50 families also showed an unexpectedly high proportion of firstdegree relatives with congenital heart disease, presumably the result of the chances of sampling. One mother had a mild congenital heart lesion (aortic stenosis), and in 2 of the 105 sibs one girl had been operated upon for an atrial septal defect and the second child almost certainly had a small ventricular septal defect.

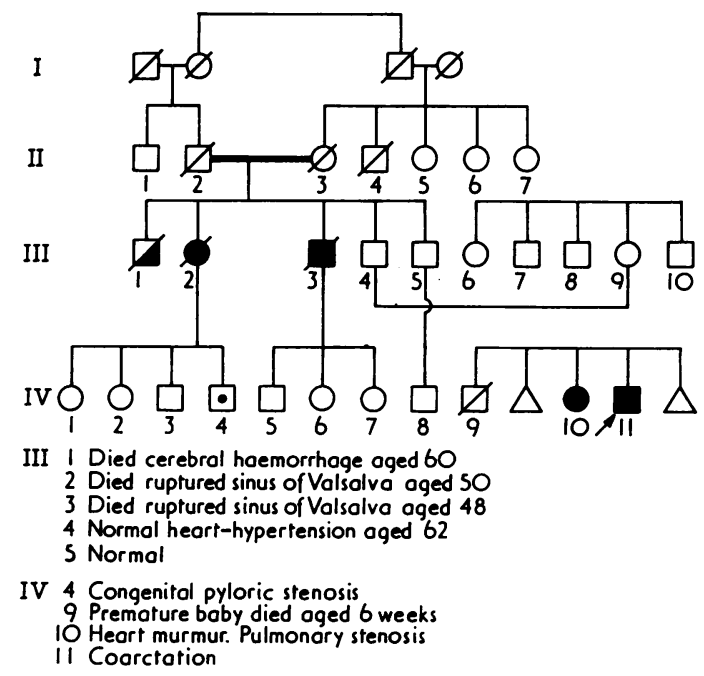

FIG. 3. Pedigree of G.B. No. 46 
One family (Fig. 3) produced two affected seconddegree relatives. The propositus had an uncomplicated coarctation of the 'adult' type and a bicuspid aortic valve. The paternal grandparents were first cousins, who had produced 5 offspring. Two of these died in middle age from a ruptured sinus of Valsalva and have been classified as having partially concordant lesions (there was no evidence of Marfan's syndrome in the one necropsy report available); another died from cerebral haemorrhage; the fourth has hypertension, but a normal heart and is the father of the propositus; and the fifth appears to be unaffected. In the control series none of the 551 second-degree relatives was found to be affected.

Among third-degree relatives of propositi, 7 were found to have a congenital heart lesion. Two had a coarctation and one had a congenital aortic stenosis (partially concordant). One index patient had 2 affected first cousins, a girl dying in infancy with a coarctation and ventricular septal defect, and her sister surviving with an uncomplicated ventricular septal defect. Two had been operated upon for a persistent ductus arteriosus which is sometimes associated with a coarctation, but these and 2 other affected relatives were regarded as having discordant lesions.

The total number of fourth- and fifth-degree relatives could not be accurately assessed, but in each group there were 4 known to be affected with a congenital heart defect, 1 of whom was concordant, 1 partially concordant, and 2 discordant. In the control series there was only 1 affected second cousin from an unknown total of remote relatives.

\section{Associated malformations}

The incidence of associated malformations among the propositi was considerably lower than in surveys of other congenital heart conditions (Campbell and Goodwin, 1965; Emanuel et al, 1968; Boon et al, 1972), but higher than in the general population. Among the male index patients, 1 had a right internal strabismus and 1 had a large naevus on his back, and 1 child was autistic. Serious defects were more frequent in the female index patients; 1 child had been operated upon for cleft lip and pyloric stenosis in early infancy. Two others had duplex kidneys and a fourth had an ectopic right kidney. This incidence of $7 \%$ associated defects corresponds with the findings of Campbell and Polani (1961) and Lamy et al (1957).

The incidence of non-cardiac malformations among the sibs of the index patients is much lower and compares with that in sibs of the control series. In the former (217 sibs), 3 were stillborn with neural tube defects ( 1 anencephalic and 2 hydroce- phalic). One brother had died at the age of 6 years with a cerebral tumour and a sister had had a gross umbilical hernia necessitating operation at the age of 4 years. Five sibs had died from a non-congenital disease, soon after birth or in early childhood. Among the 107 sibs of the control series, 1 child had polydactyly and another a small cleft of the soft palate. The figures in both of these groups are consistent with the $2 \%$ incidence of congenital defects in the general population as observed by other authors, e.g. $2.6 \%$ by Williamson (1969) and $2.5 \%$ by McKeowan and Record (1960).

\section{Discussion}

This survey of coarctation of the aorta is unsatisfactory in several ways. It does not refer to consecutive cases from a series of births, but to all those diagnosed over a period, irrespective of whether they were adults or children, so that years separated the times of their individual embryological development during which the factors relevant to the coarctation may have altered. This mode of ascertainment may well affect the series and its interpretation. For example, the inclusion of cases surviving to adulthood means that the series may not give a true representation of the distribution of degrees of severity or of the association with other severe conditions, for the most severely affected may not have survived. But the effect of this bias, if any, on the family inquiry would be unidirectional, for if there were a pronounced association of the degree of severity in the propositus and a positive family history, it would tend to underestimate the occurrence in other family members. Secondly, the condition is clearly heterogeneous in morphology and development, and the different forms may be brought about in different ways. Certainly any genetic involvement may be due to different gene sets in the different types of condition, and this appears particularly likely from the embryological differences. Thirdly, when the present series is broken down, there are relatively few cases in each of the subtypes, particularly when the obviously important factor of sex is also taken into account. However, coarctation of the aorta is recognized as a clinical entity, other studies of factors involved in the aetiology have regarded it as such, and the results of the current survey are, therefore, presented, but with the reservation that they may require modification when further data on the subtypes of the condition become available.

\section{Subjects}

It is difficult to compare the distribution of types, 
on account of terminology and classification differences. In the series of Chang and Burrington (1972), the majority of cases in infants under 1 year were preductal (78 out of 90 ), but only a minority in children and adults (4 out of 30). In the present series, of the 59 cases diagnosed before the age of 1 year, only 13 were preductal, while of the 41 diagnosed after the age of 1 year, none was of the preductal variety. This difference may well reflect a difference in the referral of patients for investigation and treatment.

A striking feature of this survey is the wide variation in the age at diagnosis of coarctation. This is a direct reflection of the variation in mode of development and degree of severity of the condition. While almost all the cases with other associated cardiac defects (30 including 13 babies with preductal type coarctation) and 29 cases of 'adult' coarctations were diagnosed within the first year of life, there remained a further 41 patients whose age at diagnosis ranged from 2 to $\mathbf{4 0}$ years, with a mean of 6 to 7 years. By contrast, children with Fallot's tetralogy were diagnosed at 3 months on average (Boon et al, 1972). Lamy et al (1957) gave a mean of 3 to 6 years for the diagnosis of all types of congenital heart disease. Keith et al (1958) noted the lack of symptoms in healthy children found to have a heart murmur on routine school examination, or in the course of some other illness, and McNamara and Rosenberg (1968) pointed out that the diagnosis of coarctation could be missed both at operation for another cardiac defect and at necropsy.

The population incidence is understandably difficult to assess with accuracy, partly on account of the delay and difficulty in diagnosis in many cases, partly on account of the mortality to which the condition gives rise; Campbell (1970) calculated that of those patients with coarctation of the aorta who had survived the first year of life, $9 \%$ would be dead by the age of 10 years, $26 \%$ by the age of 20 , and $65 \%$ by the age of 40 . Such information as there is suggests that the incidence is similar in all races (van der Horst and Gotsman, 1972). In Britain, as in other western countries, coarctation of the aorta appears to rank 6th in frequency in necropsy statistics $(6 \%$ of all cases of congenital heart disease); van der Horst and Gotsman (1972) reported 12 coarctations in 11970 necropsies of all ages. It occurs in 5 to $6 \%$ among living patients with congenital heart disease (Watson, 1970). The incidence among U.S.A. army recruits was found to be 1 in 10000 , and in the children reported to the Liverpool Malformation Registry 3.2 per 10000 (Kenna et al, 1975, Table 1b). For the population as a whole the figure of 4 in 10000 appears reasonable.
A reduction in birthweight has been observed in children born with other types of cardiac defect. Boon et al (1972) noted a tendency to low birthweight in children with Fallot's tetralogy; Campbell and Polani (1961) remarked on the lighter birthweight of girls with coarctation compared with the boys. However, this study, which omitted the premature births, shows the reverse of their findings, with the affected girls being slightly heavier than the affected boys and their normal sisters, but this may well be the result of the sampling error attaching to the smaller numbers. The affected boys were slightly lighter than their normal brothers but this was not significant.

\section{Family environment}

The increased difference in parental age which was significant in the parents of the female, but not the male, propositi, remains unexplained. In combination with the increase in paternal age, a trend also noted by Campbell (1961) and Polani and Campbell (1955), it would point to the possible implication of genetic factors.

Seasonal variation in incidence in the birth of children with coarctation was first noted by Campbell and Polani (1961), but their 151 cases were insufficient for the pattern to allow significance. This observation was confirmed by Miettinen et al (1970) on a larger series of 560 cases of coarctation. They found an overall deficiency of cases born in April to August, while there were two peaks distinguishable in the remainder of the year; these were, it seems, characterized by different frequencies of location of the coarctation, sex, and the presence of associated anomalies. This is supported by the present highly significant birth season variation in the male cases; the excess is most pronounced from October to December. It suggests the influence of different exogenous factors operating at different times of the year. The pattern is slightly different in the rather fewer female propositae where there is an excess in the number of affected born from January to March. Whether this is a chance variation or whether it represents a real sex difference requires further investigation. But certainly the results suggest that the state of health of the mothers during the first trimester may be of relevance. Our retrospective inquiry, however, failed to indicate any increase in virus infections which might have been an exogenous factor. Indeed, the state of health in the mothers of the propositi and of the controls were very similar, but the increase in the number of mothers of propositi taking drugs is suggestive. Few reported threatened 
TABLE VII

NUMBER OF AFFECTED RELATIVES BY DEGREE OF RELATIONSHIP

\begin{tabular}{|c|c|c|c|c|c|c|c|}
\hline \multirow{2}{*}{$\begin{array}{c}\text { Degree of } \\
\text { Relationship }\end{array}$} & \multirow{2}{*}{$\begin{array}{c}\text { No. of } \\
\text { Relatives }\end{array}$} & \multirow{2}{*}{$\begin{array}{l}\text { No. } \\
\text { Affected }\end{array}$} & \multirow{2}{*}{$\begin{array}{c}\text { No. } \\
\text { Concordant }\end{array}$} & \multirow{2}{*}{$\begin{array}{c}\text { No. } \\
\text { Partially } \\
\text { Concordant }\end{array}$} & \multirow{2}{*}{$\begin{array}{l}\text { No. } \\
\text { Discordant }\end{array}$} & \multicolumn{2}{|c|}{ Controls } \\
\hline & & & & & & No. of Relatives & No. Affected \\
\hline $\begin{array}{l}\text { Parents } \\
\text { 1st-degree sibs } \\
\text { 2nd-degree: } \\
\text { Half-sibs } \\
\text { Others } \\
\text { 3rd-degree } \\
\text { 4th-degree } \\
\text { 5th-degree }\end{array}$ & $\begin{array}{r}195 \\
212 \\
\\
21 \\
1107 \\
2453 \\
\text { Many } \\
\text { Many }\end{array}$ & $\begin{array}{l}2 \\
2 \\
1 \\
2 \\
7 \\
4 \\
4\end{array}$ & $\begin{array}{l}0 \\
1 \\
1 \\
0 \\
2 \\
0 \\
1\end{array}$ & $\begin{array}{l}0 \\
0 \\
0 \\
2 \\
1 \\
1 \\
0\end{array}$ & $\begin{array}{l}2 \\
1 \\
0 \\
0 \\
0 \\
4 \\
3 \\
3\end{array}$ & $\begin{array}{r}100 \\
105 \\
0 \\
0 \\
551 \\
1,250 \\
? \\
?\end{array}$ & $\begin{array}{l}1 \\
2 \\
0 \\
0 \\
0 \\
0 \\
1\end{array}$ \\
\hline
\end{tabular}

abortions in early pregnancy compared with the mothers in the Fallot's series.

\section{Family study}

The family data are worth closer examination. Out of a total of 212 liveborn sibs of the propositi, there were 2 affected with congenital heart disease, both sisters of (different) male propositi; in 1 case the child died of a lesion similar to that of her brother, in the other she had pulmonary stenosis. Of the parents of the propositi, 2 mothers had a congenital heart defect, both ventricular septal defects. Thus out of 405 first-degree relatives, 4 were affected, 1 concordantly.

As regards more distant relatives, 1128 seconddegree relatives of the propositi were traced, of whom 3 were found to have some congenital heart defect. One was a half-sib of a female proposita, the other 2 an aunt and an uncle of one male propositus (the brother and sister of the father); both died of ruptured sinus of Valsalva. There were also 2453 third-degree relatives of the propositi, 7 of whom were affected. Of the 2 cousins of the female cases, 1 had coarctation of the aorta with ventricular septal defect, the other a ventricular septal defect; those of the male cases included 1 aortic stenosis, 1 coarctation, 2 persistent ductus, and 1 ventricular septal defect. Other cases of congenital heart disease have been identified in more remote relatives of the propositi, but it is not possible to derive an incidence figure since at this distance of relationship bias is very likely to enter into the reporting.

This family study of coarctation of the aorta shows that there is a tendency for family aggregation to occur, but not to such a pronounced degree as in Fallot's tetralogy (Boon et al, 1972). The relatively low family incidence found in this survey was also noted by Campbell and Polani (1961) in a series of 151 patients with coarctation when only 1 sib from a total of 252 was discovered to have an identical lesion to the proband. However, Lamy et al (1957) found 2 affected out of 78 normal sibs of 54 propositi. The observation in our series that 2 of 212 normal sibs were affected, 1 with a lesion regarded as concordant, an incidence of $1 \%$, is very similar to that of Campbell and Polani (1961); the 4 more sibs with heart murmurs considered to be clinically insignificant were regarded as irrelevant in this context. In view of the fact that it is rare to find congenital heart disease in the parents of the propositi (Lamy et al, 1957) the occurrence of 2 mothers of propositi with a ventricular septal defect is of interest.

That genetic factors are involved in the development of congenital heart disease is suggested by the numerous reports of occurrences in twins (e.g. Lamy et al, 1957; Uchida and Rowe, 1957; Ross, 1959; Folger, 1968), and the increased proportion of concordant heart lesions in monozygous pairs by comparison with dizygous (Nora et al, 1967). second clue to the involvement of genetic mechan ism in coarctation of the aorta is the frequent occur? rence of this anomaly with Turner's syndrome (Wilkins and Fleishman, 1944). It appears worth while to attempt to measure the extent of genetic involvement.

Tentative estimates of the hereditary component of coarctation of the aorta can be made from the family data collected here, though there are difficulties (Boon et al, 1972) on account of the limitations of the survey itself, the small number of affected relatives which inflates the standard errors, and the limited knowledge of the incidence of the condition in the general population and of the precise mode of inheritance; for present purposes a multifactorial aetiology with a polygenic component to the liability appears a reasonable hypothesis. The control families in the present investigation were too few to give the incidence in relatives of different degrees, so the general population incidence has to be employed. The first estimate uses the population figure of 4 per 10000 (3 in 10000 for males, 1 in 10000 for females). The heritability derived from sibs (ignoring the association with sex) is $41.9 \% \pm 20$, from second-degree relatives $63.2 \% \pm$ 28 , and from third-degree $71.5 \% \pm 48$. The pooled 
heritability calculated from relatives of all three degrees is $62.2 \% \pm 15$. Another set of figures may be derived using the Liverpool congenital malformation study to give (probably more reliably) the population incidence. The result is little different. The figure from sibs is $45.3 \% \pm 20$. From seconddegree relatives it is $70.0 \% \pm 25$, from third-degree $87.2 \% \pm 49$, and the pooled heritability figure calculated from first, second, and third-degree relatives is $57.9 \% \pm 15$. These tentative estimates of the heritability of liability to develop coarctation of the aorta appear acceptable. By comparison with the estimates for Fallot's tetralogy (from sibs $53.9 \% \pm$ 16 , from all relatives $45.4 \% \pm 14$ ), the coarctation figures derived from sibs are slightly lower while those pooled over all degrees are slightly higher. They are lower than the heritability of $69 \% \pm 9$ for liability to atrial septal defect calculated by Williamson (1969). The lower heritability from sibs is compatible with the suggestion from the present survey that there may be rather more enviromental influence on the development of coarctation. Too much weight should of course not be placed on these figures until the reliability of the estimates from the more distant relatives can be improved. However, from them assurance can with certainty be given to patients who have survived to reproductive age, to the many more now able to do so as a result of surgical procedures, and to other members of families in which affected individuals occur. For from these figures the expected proportion of seconddegree relatives affected with coarctation is approximately 1 in 430 and of third-degree relatives 1 in 1000.

\section{Associated malformations}

The increase in non-cardiac malformations noted in cases of Fallot's tetralogy (16\% of cases, Boon et al, 1972) was again apparent in the coarctation series, but fewer were so affected (7\%). A similar observation was also made by Lamy et al (1957), that the incidence of non-cardiac defects in their coarctation group was the lowest $(7.4 \%)$ while the highest occurred in atrial septal defect patients $(26.8 \%)$.

The mechanism responsible for the association is still far from clear, and the malformations with all their variety seem to have little in common. Coarctation, though perhaps to a lesser extent than other types of congenital heart disease, seems to involve in some patients a failure of control of normal development which may manifest in a variety of organs and tissues.

In conclusion, this family study of coarctation of the aorta shows the tendency for familial aggrega- tion to occur, not only of the same lesion, but other heart lesions also, a tendency that is shared with other congenital heart disease. This, and other evidence, points to the importance of genetic factors in the aetiology, and on the assumption that these operate in a polygenic system, the study indicates a positive fairly high heritability, not very different from that in Fallot's tetralogy. A positive family history is the only aetiological variable to emerge conclusively, but there is still ample scope for environmental factors to operate, affecting not only the development of the condition but also its severity and perhaps the development of associated non-cardiac malformations which occur at higher frequency in the propositi than in their sibs. The environmental variables that may be involved include parental age, particularly that of the father, season of birth and hence of early embryonic development which may reflect a maternal health factor.

Acknowledgments are gratefully made to Dr Stuart Hunter, Dr F. S. Jackson, Dr P. Szekely, Dr C. B. Henderson, and Mr A. Blesovsky for their interest and enthusiasm; to the general practitioners for their cooperation and permission to visit the families, and the care with which they selected controls for the study; to Dr G. A. Neligan for making available data collected by the Newcastle Maternity Survey, 1960 to 1962 ; and above all to Dr Marion Farmer for her encouragement in developing this work and her constant guidance. This work could not have been undertaken without the support of the British Heart Foundation, for which we express our gratitude.

\section{REFERENCES}

Abbott, M. E. (1928). Coarctation of the aorta. American Heart Fournal, 3, 392-618.

Blackford, L. M. (1928). Coarctation of the aorta. Archives of Internal Medicine, 41, 702-735.

Bonnet, L. M. (1903). Sur la lesion dite stenose congenitale de l'aorta dans la region de l'isthme. Revue Médicale (Paris), 23, 108-112.

Boon, A. R., Farmer, M. B., and Roberts, D. F. (1972). A family study of Fallot's tetralogy. Fournal of Medical Genetics, 9, 179192.

Campbell, M. (1970). Natural history of coarctation of the aorta. British Heart fournal, 32, 633-640.

Campbell, M. and Goodwin, J. (1965). Some factors in the etiology of VSD. Progress in Cardiovascular Diseases, 7, 417-432.

Campbell, M. and Polani, P. E. (1961). The aetiology of coarctation of the aorta. Lancet, 1, 463-468.

Chang, J. H. T. and Burrington, J. D. (1972). Coarctation of the aorta in infants and children. Fournal of Pediatric Surgery, 7, $127-135$

Emanuel, R., Nichols, J., Anders, J. M., Moores, E. C., and Somerville, J. (1968). Atrioventricular defects-a study of 92 families. British Heart fournal, 30, 645-653.

Folger, G. M. (1968). Tetralogy of Fallot in twins. Southern Medical fournal, 61, 64-67.

Johnson, A. L., Ferencz, C., Wiglesworth, F. W., and McRae, D. L. (1951). Coarctation complicated by patency of the ductus arteriosus: physiologic considerations in the classification of coarctation of the aorta. Circulation, 4, 242-250. 
Keith, J. D., Rowe, R. D., and Vlad, P. (1958). Heart Disease in Infancy and Childhood, p. 173. McMillan, New York.

Kenna, A. P., Smithells, R. W., and Fielding, D. W. (1975). Congenital heart disease in Liverpool, 1960-69. Quarterly fournal of Medicine, 44, 17-44.

Lamy, M., de Grouchy, J., and Schweisguth, O. (1957). Genetic and non-genetic factors in the etiology of congenital heart disease: a study of 1188 cases. American fournal of Human Genetics, 8, $17-41$

Le Grand (1835). Cited by McNamara and Rosenberg (1968). Coarctation of the aorta. In Paediatric Cardiology, p. 175. Ed. by $H$. Watson. Lloyd-Luke, London.

McKeowan, T. and Record, R. G. (1960). Ciba Foundation Symposium on Congenital Malformations, p. 2. Churchill, London.

McNamara, D. G. and Rosenberg, H. S. (1968). Coarctation of the aorta. In Paediatric Cardiology, p. 175 . Ed. by H. Watson. Lloyd-Luke, London.

Miettinen, O. S., Reiner, M. L., and Nadas, A. S. (1970). Seasonal incidence of coarctation of the aorta. British Heart fournal, 32, 103-107.

Morgagni, J. B. (1760). De sedibus et causis Morborum. Epist. $X V I I I$, Art 6, 1, 462. Remondini, Venice.

Nora, J. J., Gilliland, J. C., Somerville, R. J., and McNamara, D. G. (1967). Congenital heart disease in twins. New England fournal of Medicine, 277, 568-571.

Oppolzer (1848). Obliteration der Aorta. Vierteljahrsschrift fïr die praktische Heilkunde, 19, 69.
Penrose, L. S. (1955). Paternal age and mutation. Lancet, 2, 312313.

Polani, P. E. and Campbell, M. (1955). An etiological study of congenital heart disease. Annals of Human Genetics, 19, 209-230.

Registrar General (1960). Classification of Occupation. H.M.S.O., London.

Ross, L. J. (1959). Congenital cardiovascular anomalies in twins. Circulation, 20, 327-342.

Taussig, H. B. (1960). Congenital Malformations of the Heart, 2nd ed., p. 785. Harvard University Press for Commonwealth Fund, Cambridge, Massachusetts.

Uchida, I. A. and Rowe, R. D. (1957). Discordant heart murmurs in twins. American fournal of Human Genetics, 9, 133-140.

van der Horst, R. L. and Gotsman, M. S. (1972). Racial incidence of coarctation of aorta. British Heart fournal, 34, 289-294.

Watson, H. (1970). Classification of Heart Disease in Childhood. International Society of Cardiology, Groningen, Netherlands.

Wernicke, R. (1875). Die Verengerung und Obliteration de Aorta in de Gegend des Ductus Arteriosus Botalli und ihre Diagnose intra Vitam. Gustav Lange, Berlin.

Wilkins, L. and Fleishman, W. (1944). Ovarian agenesis : pathology, associated clinical symptoms and the bearing on the theories of sex differentiation. Fournal of Clinical Endocrinology and Metabolism, 4, 357-375.

Williamson, E. M. (1969). A family study of atrial septal defect, fournal of Medical Genetics, 6, 255-265.

\section{APPENDIX I}

\section{COARCTATION OF AORTA}

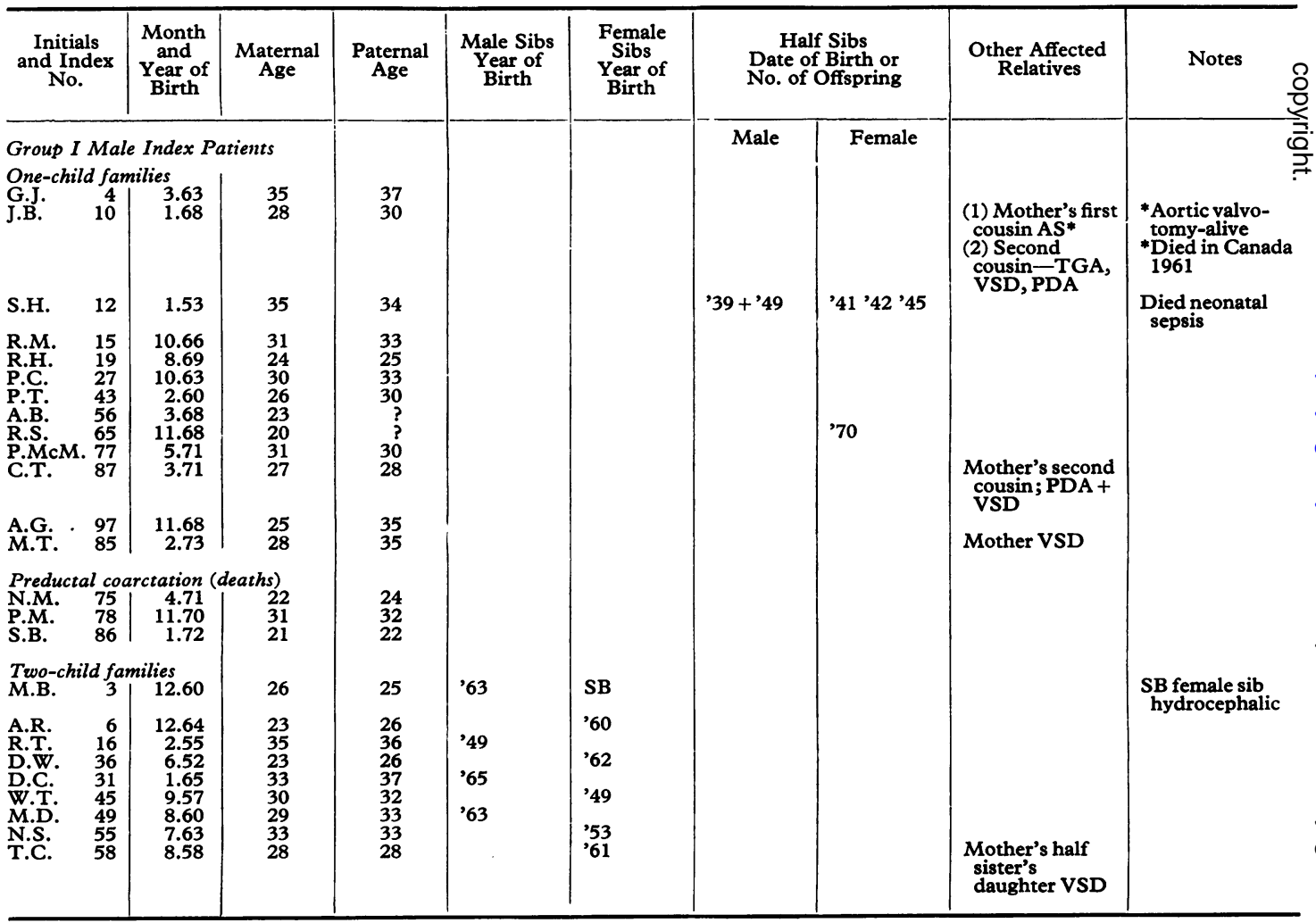


Appendix I-continued

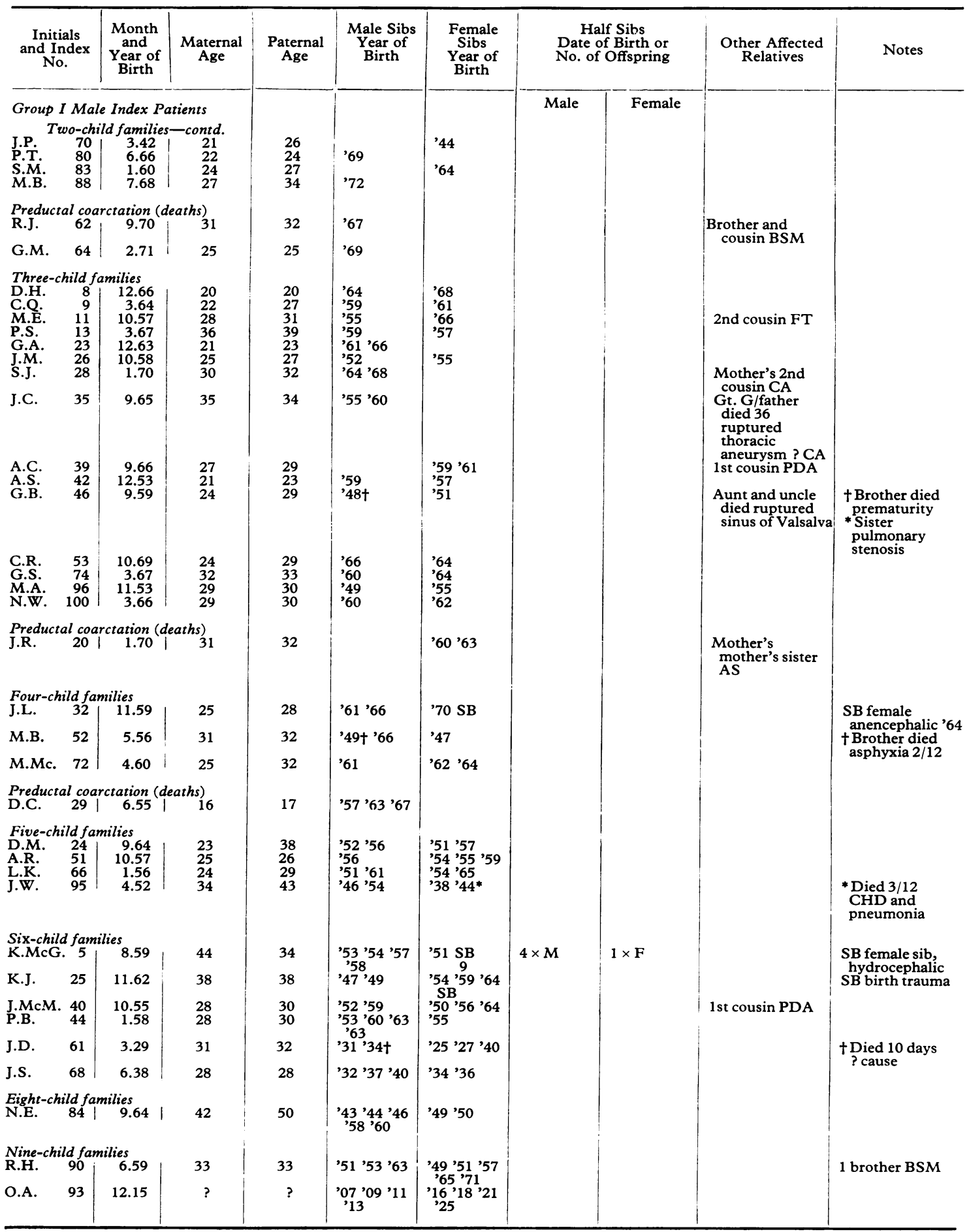


Appendix I-continued

\begin{tabular}{|c|c|c|}
\hline $\begin{array}{l}\text { Initials } \\
\text { and Index } \\
\text { No. }\end{array}$ & $\begin{array}{l}\text { Month } \\
\text { and } \\
\text { Year of } \\
\text { Birth }\end{array}$ & \\
\hline \multicolumn{3}{|c|}{ Group I Male Index Patient } \\
\hline \multicolumn{3}{|c|}{$\begin{array}{l}\text { Ten-child families } \\
\text { Preductal coarctation (deaths) } \\
\text { M.R. } 1 \text { ( } 2.66\end{array}$} \\
\hline \multicolumn{3}{|c|}{ Female Index patients } \\
\hline One-child far & & \\
\hline $\begin{array}{ll}\text { J.H. } & 59 \\
\text { L.S. } & 67\end{array}$ & $\begin{array}{r}12.70 \\
2.52\end{array}$ & \\
\hline $\begin{array}{l}\text { D.B. } \\
\text { M.C. }\end{array}$ & $\begin{array}{r}10.20 \\
6.72\end{array}$ & \\
\hline 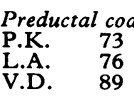 & $\begin{array}{r}\text { rctation }(d \\
4.71 \\
2.71 \\
6.71\end{array}$ & leaths \\
\hline $\begin{array}{lr}\text { Two-child fa } \\
\text { B.W. } & 2 \\
\text { K.M. } & 17 \\
\text { S.B. } & 21 \\
\text { P.F. } & 22 \\
\text { J.H. } & 34 \\
\text { K.B. } & 38 \\
\text { M.G. } & 41 \\
\text { A.T. } & 54 \\
\text { S.B. } & 79 \\
\text { M.G. } & 81 \\
\text { D.H. } & 82 \\
\text { S.J. } & 92 \\
\text { J.S. } & 98\end{array}$ & $\begin{array}{r}\text { nilies } \\
7.59 \\
1.67 \\
4.61 \\
3.62 \\
8.58 \\
7.57 \\
10.62 \\
6.68 \\
1.62 \\
6.69 \\
2.65 \\
4.47 \\
10.58\end{array}$ & \\
\hline
\end{tabular}

Preductal coarctation (deaths)

\begin{tabular}{ll|l|l} 
J.R. & 33 & 6.70 & 23 \\
P.M. & 63 & 8.70 & 22
\end{tabular}

Three-child families

A.R. $18|12.65| 20$

\begin{tabular}{ll|r|r} 
B.L. & 30 & 9.58 & 27
\end{tabular}

\begin{tabular}{ll|l|l} 
R.W. & 37 & 3.58 & 32 \\
S.C. & 47 & 3.58 & 21
\end{tabular}

Four-child families

\begin{tabular}{ll|r|r} 
A.S. & 50 & 8.60 & 24 \\
F.B. & 91 & 12.60 & 22
\end{tabular}

Five-child families

\begin{tabular}{l|l|l} 
Five-child families & \\
C.G. $7,11.64$ &
\end{tabular}

\begin{tabular}{ll|l|l} 
G.H. & 14 & 3.55 & 33
\end{tabular}

Six-child families

\begin{tabular}{l|l|l|} 
S.M. $57 \mid 20$ & 2.63
\end{tabular}

B.G. $60 \quad 3.35 \quad$ ?

Eight-child families
Y.M. $48|6.50|$

Nine-child families

S.M. $71^{1} 1.57 \mid 25$

\begin{tabular}{ll|l|l} 
A.H. & 94 & 4.43 & 26
\end{tabular}

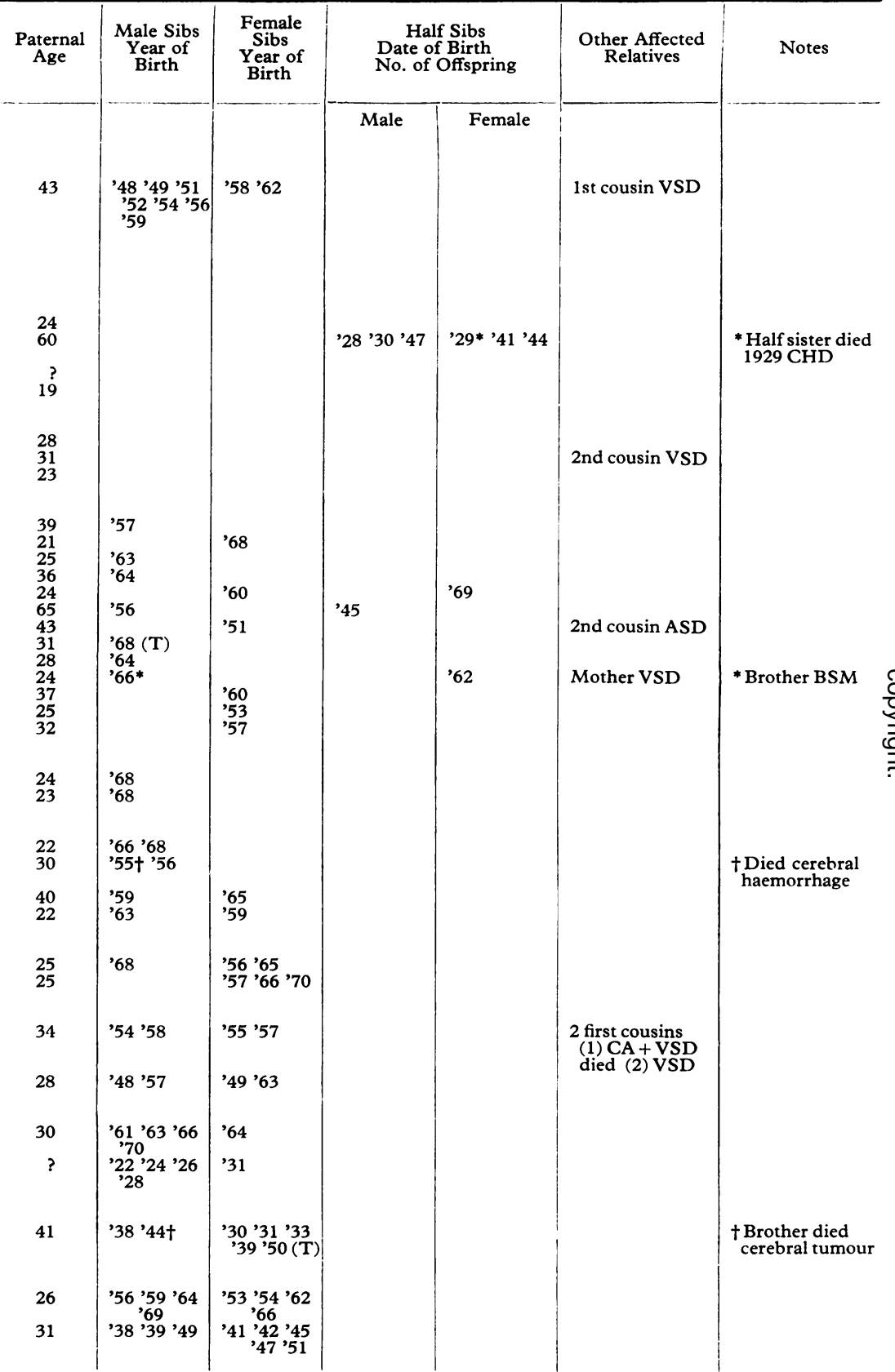


APPENDIX II

AFFECTED RELATIVES

\begin{tabular}{|c|c|c|c|c|c|}
\hline Index No. & Ist degree & 2nd degree & 3rd degree & 4th degree & 5th degree \\
\hline $\begin{array}{l}\text { Males } \\
\text { M.R. } 1\end{array}$ & & & Father's brother's son, & & \\
\hline $\begin{array}{l}\text { J.B. } 10 \\
\text { M.E. } 11\end{array}$ & & & VSD & $\begin{array}{l}\text { Mother's father's } \\
\text { sister's son, cong. } \\
\text { AS }\end{array}$ & $\begin{array}{l}\text { Mother's father's } \\
\text { brother's daughter's } \\
\text { son, died TGA 1961 } \\
\text { Father's mother's } \\
\text { brother's son's son, } \\
\text { FT }\end{array}$ \\
\hline J.R. $\quad 20$ & & & $\begin{array}{l}\text { Mother's mother's } \\
\text { sister, cong. AS }\end{array}$ & & \\
\hline S.J. $\quad 28$ & & & & & $\begin{array}{l}\text { Mother's mother's } \\
\text { sister's son's son, CA }\end{array}$ \\
\hline J.C. 35 & & & Father's mother's & & \\
\hline A.C. 39 & & & Mother's mother's son, & & \\
\hline J.M. 40 & & & $\begin{array}{l}\text { Father's brother's } \\
\text { daughter, PDA }\end{array}$ & & \\
\hline G.B. 46 & Sister PS & $\begin{array}{l}\text { Father's brother, } \\
\text { father's sister, } \\
\text { ruptured sinus of } \\
\text { Valsalva }\end{array}$ & & & \\
\hline T.C. 58 & & vasoura & & $\begin{array}{l}\text { Mother's half } \\
\text { sister's daughter, } \\
\text { VSD }\end{array}$ & \\
\hline $\begin{array}{l}\text { M.T. } 85 \\
\text { C.T. } 87\end{array}$ & Mother VSD & & & $\begin{array}{l}\text { Mother's mother's } \\
\text { sister's daughter } \\
\text { PDA + VSD }\end{array}$ & \\
\hline J.W. 95 & $\begin{array}{c}\text { Sister died CHD; } \\
\text { probable C.A. }\end{array}$ & & & & \\
\hline $\begin{array}{l}\text { Females } \\
\text { C.G. } 7\end{array}$ & & & $\begin{array}{l}\text { Mother's brother's } \\
\text { daughter died, CA + } \\
\text { VSD } \\
\text { Mother's brother's } \\
\text { daughter, VSD }\end{array}$ & & \\
\hline M.G. 41 & & & & $\begin{array}{l}\text { Father's sister's } \\
\text { daughter's daughter, } \\
\text { ASD }\end{array}$ & \\
\hline $\begin{array}{ll}\text { L.S. } & 67 \\
\text { P.K. } & 73\end{array}$ & & Half sister died, CHD & & & $\begin{array}{l}\text { Father's mother's } \\
\text { sister's daughter's }\end{array}$ \\
\hline M.G. 81 & Mother, VSD & & & & \\
\hline
\end{tabular}

Cong. = congenital. Key: CA = coarctation; FT = Fallot's tetralogy; VSD = ventricular septal defect; ASD = atrial septal defect; PDA $=$

persistent ductus arteriosus; $\mathrm{AS}=$ aortic stenosis; $\mathrm{PS}=$ pulmonary stenosis; $\mathrm{CHD}=$ congenital heart disease $; \mathrm{BSM}=\mathrm{benign}$ systolic murmur

$\mathrm{TGA}=$ transposition of great arteries; $*$ = relative mentioned in Notes column; $(\mathrm{T})=\mathrm{twin} ; t=$ deceased. 